\title{
PENGARUH KOMPETENSI DOSEN TERHADAP KINERJA AKADEMIK DAN KEPUASAN MAHASISWA: STUDI KASUS KELAS INTERNASIONAL DI PROGRAM STUDI MANAJEMEN DAN AKUNTANSI FAKULTAS EKONOMI DAN BISNIS UNIVERSITAS SINGAPERBANGSA KARAWANG (2017-2018)
}

\author{
Made Panji Teguh Santoso \\ Novian Ekawaty \\ made.santoso@staff.unsika.ac.id \\ novianekawaty@gmail.com
}

\begin{abstract}
ABSTRAK
Penelitian ini mempunyai tujuan jangka panjang memberikan penyadaran bahwa kompetensi para dosen Kelas Internasional Program Studi Manajemen dan Akuntansi Fakultas Ekonomi dan Bisnis Universitas Singaperbangsa Karawang sangat mempengaruhi kepuasan dan kinerja akademik para mahasiswa mereka.

Kompetensi dosen yang dimaksud dalam penelitian ini adalah kemampuan mengajar secara paripurna, yang meliputi beberapa elemen yang saling berkaitan - pengetahuan, keterampilan, dan sikap - yang bermuara pada alih pengetahuan dari dosen tersebut kepada mahasiswanya. Kepuasan para mahasiswa yang disebutkan dalam penelitian ini adalah rasa nyaman para mahasiswa dalam belajar maupun setelah melihat hasil belajar mereka, yang berujung pada keinginan untuk ingin terus meneruskan masa belajarnya di institusi pendidikan tinggi tersebut. Kinerja akademik mahasiswa dalam penelitian ini merujuk pada pendekatan nilai total rata-rata semua mata kuliah yang diambil oleh para mahasiswa tiap semester dalam satu tahun kalender akademik.
\end{abstract}

Target khusus penelitian ini adalah memberikan gambaran konkret keadaan objektif kelas-kelas internasional di Prodi Manajemen dan Akuntasi FEB Unsika, untuk dapat dijadikan tolak ukur kualitas kegiatan belajar mengajar dan bahan evaluasi untuk perbaikan kualitas di masa depannya.

Menggunakan metode penelitian kuantitatif, penelitian ini menempatkan kompetensi sebagai variabel independen, dan kinerja akademik serta kepuasan mahasiswa sebagai variabel-variable dependennya.

Kata kunci: kompetensi, dosen, kinerja, kepuasan, mahasiswa. 


\section{PENDAHULUAN}

Peningkatan kualitas dosen menjadi salah satu fokus utama dalam sistem pendidikan nasional, terutama yang berkaitan dengan penyelenggaraan proses pendidikan oleh lembaga pendidikan, khususnya perguruan tinggi. Lulusan perguruan tinggi yang berkualitas dan terserap dalam dunia kerja tentunya memiliki implikasi pada terciptanya keungulan kompetitif secara nasional.

Dengan peran yang begitu strategis dalam proses pembelajaran di kampus, seorang dosen boleh jadi akan dianggap penyebab utama pencapaian hasil akademik yang rendah, serta sikap dan nilai yang buruk dari para mahasiswanya. Setiap universitas menginginkan dosen yang memiliki kompetensi yang unggul dan andal, sehingga mampu mendongkrak kinerja para mahasiswanya. Kompetensi dosen yang dapat ditingkatkan dan diperbaiki ditunjukkan dari perilaku dosen dalam memberikan pelayanan pendidikan berdasarkan standar pelayanan pendidikan, mandiri, bertanggungjawab, dan mengembangkan kemampuan sesuai dengan perkembangan ilmu pengetahuan dan teknologi, serta menggunakan berbagai strategi yang tepat dalam proses pembelajaran.

Universitas Singaperbangsa Karawang, sebuah institusi perguruan tinggi negeri di kota Karawang, diharapkan dapat menghasilkan lulusan-lulusan yang berkualitas, yang bisa bersaing dengan perguruan tinggi negeri lainnya terutama dalam menghadapi persaingan di dunia kerja. Usaha Unsika untuk menghasilkan lulusan-lulusan yang berkualitas perlu didukung dengan berbagai usaha. Salah satunya adalah dengan memastikan kompetensi dosen yang optimal dan kepuasan belajar yang tinggi dari para mahasiswa.

Untuk menciptakan lulusan yang berkualitas, Fakultas Ekonomi dan Bisnis (FEB) Unsika sudah dua tahun ini membuat terobosan baru dengan membuka kelas-kelas internasional. Kelas-kelas internasional adalah kelas-kelas yang mana seluruh kegiatan perkuliahan di dalamnya diberikan dalam bahasa pengantar Bahasa Inggris. Namun demikian, usaha untuk meningkatkan kualitas lulusan lewat pembukaan kelas-kelas internasional ini mendapatkan hambatan. Kelas-kelas internasional ini membutuhkan para dosen pengajar yang bukan hanya menguasai dan dapat memberikan materi perkuliahan dengan baik, namun mereka juga dituntut untuk dapat berkomunikasi yang baik dalam Bahasa Inggris secara lisan maupun tulisan. 
Berdasarkan beberapa substansi permasalahan yang diuraikan diatas, maka kami tertarik untuk melakukan penelitian dengan judul: "Pengaruh Kompetensi Dosen Terhadap Kinerja Akademik dan Kepuasan Mahasiswa: Studi Kasus Kelas International di Program Studi Manajemen dan Akuntansi Fakultas Ekonomi \& Bisnis Universitas Singaperbangsa Karawang (2017-2018) ${ }^{6}$.

Berdasar pembatasan masalah tersebut, dapat dirumuskan lebih lanjut masalah penelitian, sebagai berikut:

1. Bagaimana kompetensi dosen kelas Internasional Fakultas Ekonomi dan Bisnis Universitas Singaperbangsa Karawang Karawang?

2. Bagaimana Kinerja Akademik kelas Internasional Fakultas Ekonomi dan Bisnis Universitas Singaperbangsa Karawang?

3. Bagaimana Kepuasan Mahasiswa kelas Internasional Fakultas Ekonomi dan Bisnis Universitas Singaperbangsa Karawang?

4. Seberapa besar pengaruh secara parsial kompetensi dosen dan kinerja akademik terhadap kepuasan mahasiswa kelas Internasional Fakultas Ekonomi dan Bisnis Universitas Singaperbangsa Karawang?

5. Seberapa besar pengaruh secara simultan kompetensi dosen dan kinerja akademik terhadap kepuasan mahasiswa kelas Internasional Fakultas Ekonomi dan Bisnis Universitas Singaperbangsa Karawang?

\section{Kompetensi}

Menurut Spencer dalam Sudarmanto (2009: 53), komponen-komponen kompetensi mencakup beberapa hal berikut :

1. Motives adalah sesuatu yang secara konsisten dipikirkan atau dikehendaki seseorang yang menyebabkan tindakan. Motif menggerakkan, mengarahkan, dan menyeleksi perilaku terhadap kegiatan atau tujuan tertentu dan menjauh dari orang lain.

2. Traits adalah karakteristik-karakteristik fisik dan respon-respon konsisten terhadap berbagai situasi atau informasi.

3. Self concept adalah sikap, nilai, dan citra diri seseorang.

4. Knowledge adalah pengetahuan atau informasi seseorang dalam bidang spesifik tertentu 
5. Skill adalah kemampuan untuk melaksanakan tugas fisik tertentu atau tugas mental tertentu.

\section{Kinerja}

Umar yang mengutip Erich dan Gilmore (2010: 11) menyebutkan ciri-ciri individu yang mempunyai kinerja dan produktif, yaitu: 1) tindakannya konstruktif, 2) percaya diri, 3) mempunyai rasa tanggung jawab, 4) memiliki rasa cinta terhadap pekerjaannya, 5) mempunyai pandangan ke depan, 6) mampu menyelesaikan persoalan.

\section{Kepuasan}

Menurut Edy Sutrisno (2013: 80) faktor yang mempengaruhi kepuasan kerja adalah:

1. Faktor psikologis, yaitu faktor yang berhubungan dengan kejiwaan seseorang yang meliputi minat, ketentraman dalam kerja, sikap, bakat dan ketrampilan.

2. Faktor sosial, yaitu faktor yang berhubungan dengan interaksi sosial antara karyawan maupun karyawan dengan atasan.

3. Faktor fisik, yaitu faktor yang berhubungan dengan kondisi fisik karyawan, meliputi jenis pekerjaan, pengaturan waktu dan waktu istirahat, perlengkapan kerja, keadaan ruangan, suhu, penerangan, kondisi kesehatan, dan umur.

4. Faktor finansial, yaitu faktor yang berhubungan dengan jaminan serta kesejahteraan.

\section{Hubungan Kompetensi dengan Kinerja}

Moeheriono yang mengutip Spencer (2010: 8) menyatakan kompetensi mempunyai hubungan sebab-akibat jika dikaitkan dengan kinerja seorang karyawan serta kompetensi yang terdiri dari motif, sifat, konsep diri dan keterampilan, serta pengetahuan, yang diharapkan dapat memprediksikan perilaku seseorang sehingga pada akhirnya dapat memprediksi kinerja orang tersebut.

\section{Hubungan Kompetensi dengan Kepuasan}

Menurut Edy Sutrisno (2013: 206) kompetensi tidak datang begitu saja, melainkan harus diciptakan terutama melalui sumber daya manusia yang efektif dan efisien. Pengelolaan dengan orientasi layanan diperlukan untuk mencegah ketidaksesuaian pengelolaan sumber daya manusia. Dengan berorientasi pada layanan, ketidaksesuaian dapat diminimalkan atau bahkan 
dihilangkan. Dampak positif orientasi pada layanan adalah peningkatan kepuasan kerja mereka, dan sumber daya manusia yang puas akan selalu berusaha sekuat tenaga memuaskan kebutuhan dan keinginan.

\section{Hubungan Kinerja dengan Kepuasan}

Karyawan yang merasa puas akan lebih mungkin terlibat dalam organisasi yang dapat meningkatkan produktivitas, sedangkan karyawan yang tidak merasa puas maka akan mempengaruhi berjalannya organisasi dalam pencapaian tujuan.

Menurut Mathis dan Jackson (2008: 70) kepuasan kerja adalah keadaan emosional yang positif, yang merupakan hasil evaluasi pengalaman kerja seseorang. Kepuasan kerja itu meliputi pekerjaan, upah, kesempatan promosi, pengawasan, dan mitra kerja. Karyawan yang setia adalah mereka yang lebih dari puas dengan pekerjaan mereka, namun mereka juga puas dengan hubungan mereka dengan atasan.

Perumusan hipotesis penelitian dikemukakan setelah landasan teori dan kerangka berpikir. Hipotesis merupakan jawaban sementara terhadap rumusan masalah penelitian, di mana rumusan masalah penelitian telah dinyatakan dalam bentuk kalimat pertanyaan. Dikatakan sementara, karena jawaban yang diberikan baru didasarkan pada teori yang relevan, belum didasarkan pada fakta-fakta empiris yang diperoleh melalui pengumpulan data. Jadi, hipotesis juga dapat dinyatakan sebagai jawaban teoritis terhadap rumusan masalah penelitian, belum jawaban yang empirik. (Sugiyono, 2013: 64)

Berdasarkan kerangka berpikir dan paradigma penelitian, maka dapat disusun hipotesis sebagai berikut ini.

1. Terdapat hubungan kompetensi dosen dan kinerja akademik Kelas Internasional Fakultas Ekonomi dan Bisnis Universitas Singaperbangsa Karawang.

2. Terdapat pengaruh kompetensi dosen terhadap kinerja akademik Kelas Internasional Fakultas Ekonomi dan Bisnis Univrsitas Singaperbangsa Karawang.

3. Terdapat pengaruh kinerja akademik terhadap kepuasan mahasiswa Kelas Internasional Fakultas Ekonomi dan Bisnis Universitas Singaperbangsa Karawang. 
4. Terdapat pengaruh secara parsial dan simultan kompetensi dosen dan kinerja akademik terhadap kepuasan mahasiswa Kelas Internasional Fakultas Ekonomi dan Bisnis Universitas Singaperbangsa Karawang.

\section{METODE PENELITIAN}

\section{Jenis Penelitian}

Penelitian ini dilakukan untuk menjelaskan hubungan dua variabel yaitu variabel bebas dengan variabel terikat, maka jenis penelitian yang digunakan kuantitatif dengan jenis asosiatif, karena peneliti ingin mengetahui ada tidaknya pengaruh antara variabel-variabel melalui pengujian hipotesa yang telah dirumuskan.

Tujuan dari penelitian deskriptif adalah untuk membuat deskripsi, ciri-ciri, gambaran atau lukisan secara sistematis, faktual, dan akurat dengan lokasi penelitian pada Kelas International Program Studi Manajemen dan Akuntansi Fakultas Ekonomi dan Bisnis Karawang. Objek yang diteliti adalah kompetensi dosen terhadap kinerja akademik dan kepuasan mahasiswa. Metode pengumpulan data yang dipakai adalah observasi, wawancara dan kuesioner.

\section{Tempat dan Waktu Penelitian}

Penelitian dilakukan di Kelas Internasional Program Studi Manajemen dan Akuntasi Fakultas Ekonomi dan Bisnis Universitas Singaperbangsa Karawang, yang akan dilaksanakan mulai bulan Juli 2017 sampai dengan bulan Juni 2018 melalui pengumpulan data, pengolahan data dan analisia data sehingga diperoleh hasil mengenai Kompetensi Dosen, Kinerja Akademik dan Kepuasan Mahasiswa.

\section{Target Penelitian}

Penelitian ini menggunakan data primer, yang merupakan data-data yang diperoleh dengan cara langsung dari sumbernya lewat wawancara, kuesioner, serta observasi langsung di tempat penelitian. Selain itu penelitian ini juga menggunakan data sekunder, yang merupakan data-data 
yang diperoleh dari buku-buku yang ada di tempat penelitian maupun literatur yang mendukung data-data penelitian.

\section{Prosedur Penelitian}

\section{1) Kuesioner (angket)}

Kuesioner yaitu pengumpulan data yang dilakukan dengan cara memberi seperangkat pertanyaan tertulis kepada responden untuk dijawabnya. Kuesioner merupakan teknik pengumpulan data yang efisien bila peneliti tahu dengan pasti variabel yang akan diukur dan tahu apa yang bisa diharapkan dari responden. (Sugiyono, 2013: 142)

\section{2) Wawancara}

Wawancara digunakan sebagai teknik pengumpulan data apabila peneliti ingin melakukan studi pendahuluan untuk menemukan permasalahan yang harus diteliti. Teknik ini juga digunakan apabila peneliti ingin mengetahui hal-hal dari responden yang lebih mendalam dan jumlah responden sedikit/kecil (Sugiyono, 2013: 137)

\section{3) Observasi}

Obsevasi sebagai teknik pengumpulan data mempunyai ciri yang spesifik bila dibandingkan dengan teknik yang lain, yaitu wawancara dan kuesioner. Jika wawancara dan kuesioner selalu berkomunikasi dengan orang, maka observasi tidak terbatas pada orang, tetapi juga pada obyek-obyek yang lain. Observasi merupakan suatu proses yang kompleks, suatu proses yang tersusun dari pelbagai proses biologis dan psikologis, dua diantaranya yang terpenting adalah proses-proses pengamatan dan ingatan. Teknik pengumpulan data dengan observasi digunakan bila, penelitian berkenaan dengan perilaku manusia, proses kerja, gejala-gejala alam dan bila responden yang diamati tidak terlalu besar. (Sugiyono, 2013: 93)

\section{Teknik Pengumpulan Data}

Menurut Sugiyono (2013) populasi adalah wilayah generalisasi yang terdiri atas objek dan subjek yang mempunyai kualitas dan karakteristik tertentu yang ditetapkan oleh peneliti untuk dipelajari dan kemudian ditarik kesimpulannya. Data penelitian dalam populasi disebut parameter yang dapat berbentuk rata-rata, proporsi, simpangan baku dan lainnya yang menjadi 
fokus penelitian yang akan dijadikan objek penelitian. Adapun yang menjadi popolasi dalam penelitian ini adalah mahasiswa kelas International Program Studi Manajemen dan Akuntansi Fakultas Ekonomi dan Bisnis Univeritas Singaperbangsa Karawang dengan jumlah mahasiswa kurang lebih 240 orang.

\section{Teknik Analisis Data}

1) Uji Validitas

Sebelum data diproses, terlebih dahulu dilakukan uji vadilitas untuk menguji kuesioner. Uji validitas ini dilakukan dengan menggunakan metode Korelasi Pearson Product Moment, di mana hasil dari seluruh kuesioner yang berupa skor dikorelasikan (Nazir, 2005). Bila perhitungan pengujian validitas menghasilkan koefisien korelasi diatas 0,30 maka dapat disimpulkan bahwa data yang diperoleh dari semua pertanyaan merupakan data valid, sedangkan koefisien korelasi dibawah 0,30 maka data yang diperoleh merupakan data yang tidak valid (Sugiyono, 2013: 126).

\section{2) Uji Reliabilitas}

Alat ukur yang digunakan dalam penelitian ini adalah kuesioner tertutup. Keandalan suatu alat ukur berarti kemampuan alat ukur tersebut untuk mengukur gejala secara konsisten. Alat pengukur data tetap menunjukan hasil ukuran yang sama, walaupun digunakan oleh orang yang sama ditempat yang berbeda, atau orang lain pada tempat yang sama.

\section{Rancangan Analisis}

\subsubsection{Analisis Deskriptif}

Analisis Statistik Deskriptif yaitu statistik yang digunakan untuk menganalisis data dengan cara mendeskripsikan atau menggambarkan data yang telah terkumpul sebagaimana adanya 
tanpa bermaksud membuat kesimpulan yang berlaku untuk umum atau generalisasi. (Sugiyono, 2013: 147). Analisis deskriptif ini meliputi analisis distribusi frekuensi, analisis rentang skala

\subsubsection{Analisis Verifikatif}

Dalam penelitian ini analisis verifikatif bermaksud untuk mengetahui hasil penelitian yang berkaitan dengan pengaruh kompetensi dosen dan kinerja akademik terhadap kepuasan mahasiswa Kelas Internasional Fakultas Ekonomi dan Bisnis Universitas Singaperbangsa Karawang. Dengan metode ini dapat diketahui berapa besarnya dampak variabel independen mempengaruhi terhadap variabel dependen. Analisis verifikatif dalam penelitian ini menggunakan Analisis Jalur dan menggunakan data hasil transformasi yaitu data internal.

\section{HASIL PENELITIAN}

\subsection{Hasil Penelitian}

Profil responden berdasarkan jenis kelamin dapat dilihat pada tabel-tabel berikut ini:

Tabel 5.2 Jumlah Responden Berdasarkan Jenis Kelamin

\begin{tabular}{|c|c|c|c|}
\hline No & Jenis Kelamin & Jumlah & $\begin{array}{c}\text { Persentase } \\
(\mathbf{\%})\end{array}$ \\
\hline 1 & Laki-laki & 38 & 36 \\
\hline 2 & Perempuan & 68 & 64 \\
\hline & Jumlah & $\mathbf{1 0 6}$ & $\mathbf{1 0 0}$ \\
\hline
\end{tabular}

Sumber: Data Primer dianalisis, 2018

Tabel 5.2 menyajikan data mengenai jenis kelamin responden, yang mana berdasarkan jenis kelamin terdapat 38 orang laki-laki (36\%) dan 38 orang perempuan (64\%). Terlihat bahwa jumlah responden perempuan lebih banyak dibandingkan dengan jumlah responden laki-laki.

Tabel 5.3 Jumlah Responden Berdasarkan Umur

\begin{tabular}{|c|c|c|c|}
\hline No & Umur & Jumlah & Presentase \\
\hline 1 & $\leq 20$ & 42 & $40 \%$ \\
\hline 2 & $20-25$ & 64 & $60 \%$ \\
\hline & Jumlah & $\mathbf{1 0 6}$ & $\mathbf{1 0 0 \%}$ \\
\hline
\end{tabular}

Sumber : Data primer dianalisis, 2018 
Tabel 5.3 menyajikan data mengenai Jumlah responden berdasarkan umur, pada tabel tersebut terlihat bahwa responden terbanyak adalah umur 20-25 tahun dengan jumlah 64 orang (60\%), dan umur $\leq 20$ tahun sebanyak 42 orang $(40 \%)$.

\section{Tabel 5.4 Jumlah Responden Berdasarkan Semester}

\begin{tabular}{|c|c|c|c|}
\hline No & Semester & Jumlah & Presentase \\
\hline 1 & II & 31 & $29 \%$ \\
\hline 2 & IV & 47 & $44 \%$ \\
\hline 3 & VI & 28 & $27 \%$ \\
\hline & Jumlah & $\mathbf{1 0 6}$ & $\mathbf{1 0 0 \%}$ \\
\hline
\end{tabular}

Sumber : Data Primer dianalisis, 2018

Tabel 5.4 menyajikan data mengenai jumlah responden berdasarkan semester, pada tabel tersebut terlihat bahwa responden dengan semester II adalah yang terbesar dengan jumlah sebanyak 31 orang (29\%), responden semester VI dengan jumlah sebanyak 28 orang (27\%), responden semester IV dengan jumlah sebanyak 47 orang (44\%).

\section{Analisis Verifikatif}

Analisis verifikatif digunakan untuk menguji kebenaran dari suatu hipotesis yang dilaksanakan melalui pengumpulan data di lapangan

\section{Analisis Korelasi Antarvariabel Endogen (X1 dan X2)}

Korelasi antar variabel endogen dalam analisis jalur merupakan persyaratan mutlak untuk hubungan jalur diantara variabel endogen dan variabel eksogen. Apabila terdapat hubungan kedua variabel endogen yang signifikan, maka berlaku hukum-hukum analis jalur dan sebaliknya apabila tidak terdapat korelasi yang signifikan diantara variabel endogen maka hanya berlaku hubungan regresi berganda saja, kecuali model hubungan jalur yang memiliki variasi hubungan yang kompleks.

Variabel endogen dalam penelitian ini Kompetensi Dosen (X1) dan Kinerja Akademik (X2). Sedangkan variabel eksogennya adalah Kepuasan Mahasiswa (Y).

Kompetensi Dosen $\left(\mathrm{X}_{1}\right)$ 


\section{0,868}

Kinerja Akademik $\left(\mathrm{X}_{2}\right)$

\section{Analisis Jalur}

Analisis jalur dalam penelitian ini akan menjelaskan pengaruh parsial dan pengaruh simultan dari Kompetensi Dosen (X1) dan Kinerja Akademik (X2) terhadap Kepuasan Mahasiswa (Y) di Universitas Singaperbangsa Karawang.

Pengaruh parsial dari Kompetensi Dosen (X1) terhadap Kepuasan Mahasiswa (Y) pada Universitas Singaperbangsa Karawang telah diteliti dan hasilnya dijelaskan melalui model dan analisis seperti dijelaskan gambar di bawah ini.

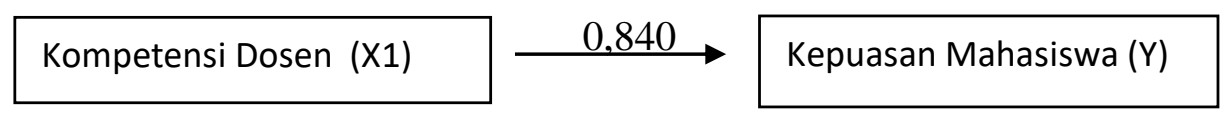

Pengaruh parsial dalam penelitian ini akan menjelaskan pengaruh secara mandiri dari variabel Endogen (Kinerja Akademik) terhadap variabel Eksogen (Kepuasan Mahasiswa) Kelas Internasional Fakultas Ekonomi dan Bisnis pada Universitas Singaperbangsa Karawang. Pengaruh parsial dari Kinerja Akademik (X2) terhadap Kepuasan Mahasiswa (Y) di Universitas Singaperbangsa Karawang telah diteliti dan hasilnya dijelaskan melalui model dan analisis seperti dijelaskan gambar di bawah ini:

0,877

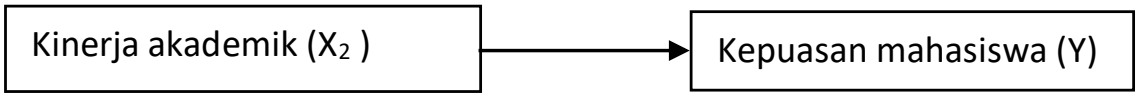

\section{Pengaruh Simultan dari X1 dan X2 terhadap Y}

Pengaruh Simultan dari Kompetensi Dosen (X1) dan Kinerja Akademik (X2) terhadap Kepuasan Mahasiswa (Y) akan menjelaskan pengaruh langsung dan pengaruh tidak langsung serta keterkaitan dan perannya dari seluruh variabel endogen terhadap variabel eksogen.

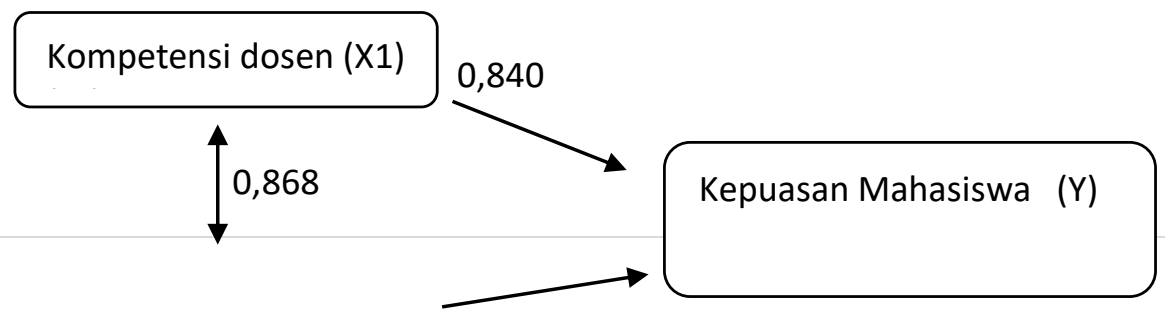




\section{Pembahasan Penelitian}

\section{Kompetensi Dosen Kelas International Fakultas Ekonomi dan Bisnis Universitas Singaperbangsa Karawang}

Hasil penelitian Kompetensi Dosen di kelas international Fakultas Ekonomi dan Bisnis Universitas Singaperbangsa Karawang menunjukkan bahwa fenomena yang paling banyak muncul modusnya adalah baik, yaitu pada skor 428-528. Hal ini menunjukkan bahwa kompetensi dosen adalah untuk memanfaatkan pengetahuan dan keterampilan kerja guna mencapai kinerja optimal. Kompetensi merupakan segala sesuatu yang dimiliki oleh pegawai berupa pengetahuan keterampilan dan faktor-faktor internal individu lainnya untuk dapat mengerjakan sesuatu pekerjaan. Kompetensi inti merupakan pemahaman terhadap visi, misi, dan nilai-nilai organisasi. Suatu kompetensi yang dihubungkan dengan strategi organisasi yang dapat diterapkan pada semua pegawai sebagai suatu keahlian unggulan suatu kompetensi. Kompetensi ini merupakan prasyarat mutlak yang harus dimiliki dosen untuk melakukan sesuatu pekerjaan unggul.

\section{Kinerja Akademik Kelas International Fakultas Ekonomi dan Bisnis Universitas Singaperbangsa} Karawang

Hasil penelitian Kinerja Akademik kelas Internasional Fakultas Ekonomi dan Bisnis Universitas Singaperbangsa Karawang menunjukkan fenomena yang paling banyak muncul atau modusnya adalah baik, yaitu berada pada skor 428-528. Hal ini menunjukkan bahwa dalam mencapai tujuan yang ditetapkan harus melalui sarana kinerja yang digerakkan sekelompok orang yang berperan aktif sebagai pelaku dalam upaya mencapai tujuan organisasi bersangkutan. Tercapainya tujuan hanya dimungkinkan karena upaya para pelaku yang terdapat pada organisasi tersebut. Dalam hal ini terdapat hubungan yang erat antara kinerja perorangan dengan kinerja organisasi, bila kinerja pegawai baik, maka kemungkinan besar kinerja organisasi juga baik. 


\section{Kepuasan Mahasiswa Kelas Internasional Fakultas Ekonomi dan Bisnis Universitas Singaperbangsa Karawang}

Hasil penelitian Kepuasan Mahasiswa kelas Internasional Fakultas Ekonomi dan Bisnis Universitas Singaperbangsa Karawang menunjukkan bahwa fenomena yang paling banyak muncul atau modusnya adalah baik, yang mana berada pada skor 428-528. Hal ini menunjukkan bahwa mahasiswa atas proses pembelajaran yang dilakukan, tersedianya bimbingan konseling bagi mahasiswa yang mengalami kesulitan dalam proses belajar dan kesempatan mendapatkan beasiswa merupakan bentuk penghargaan serta upaya menciptakan suasana nyaman dalam belajar merupakan empati yang ditunjukkan oleh universitas kepada mahasiswa. Kelengkapan prasarana kegiatan proses belajar yang dapat dilihat dengan nyata merupakan bentuk layanan fasilitas fisik yang diberikan oleh universitas kepada mahasiswa. Untuk setiap intervensi yang dilakukan atas meningkatnya kepuasan mahasiswa sebagaimana hasil penelitian, menunjukkan bahwa diharapkan peningkatan kepada mahasiswa harus terus menerus diperhatikan karena hal ini berpengaruh terhadap kepuasan mahasiswa.

\section{Hubungan Kompetensi Dosen (X1) dan Kinerja Akademik (X2)}

Hasil penelitian menunjukkan hubungan antara Kompetensi Dosen (X1) dan Kinerja Akademik (X2) di Universitas Singaperbangsa Karawang adalah sebesar 0,868 yang artinya terdapat hubungan positif kuat dua arah antara Kompetensi Dosen dan Kinerja.

\section{Pengaruh Kompetensi Dosen (X1) terhadap Kepuasan Mahasiswa (Y)}

Hasil penelitian diketahui besarnya pengaruh parsial dari Kompetensi Dosen (X1) terhadap Kepuasan Mahasiswa (Y) di Universitas Singaperbangsa Karawang adalah sebesar 0,840 artinya kompetensi dosen dapat menjelaskan perannya untuk meningkatkan kepuasan mahasiswa kelas international Fakultas Ekonomi dan Bisnis di Universitas Singaperbangsa Karawang sebesar $84 \%$.

Pengaruh Kompetensi Dosen dan Kinerja Akademik terhadap Kepuasan Mahasiswa secara Simultan

Besarnya pengaruh simultan dari Kompetensi dosen (X1) dan Kinerja akademik (X2) terhadap Kepuasan mahasiswa (Y) adalah sebesar 79,38 \% artinya Kompetensi dosen (X1) dan Kinerja 
Akademik (X2) secara bersama-sama dapat menjelaskan perannya dalam peningkatan Kepuasan Mahasiswa (Y) sebesar 79,38 \% dan terdapat faktor lain sebesar 20,62 \% peran dari faktor lain yang tidak diteliti yang dapat meningkatkan kepuasan mahasiswa kelas international Fakultas Ekonomi dan Bisnis, Universitas Singaperbangsa Karawang.

\section{KESIMPULAN DAN SARAN}

\subsection{Kesimpulan}

Berdasarkan hasil penelitian tentang pengaruh Kompetensi dosen, dan Kinerja akademik terhadap Kepuasan mahasiswa kelas International Fakultas Ekonomi dan Bisnis pada Universitas Singaperbangsa Karawang, maka dapat disimpulkan sebagai berikut.

1. Terdapat pengaruh parsial kompetensi dosen dan kinerja akademik terhadap kepuasan mahasiswa kelas international Fakultas Ekonomi dan Bisnis pada Universitas Singaperbangsa Karawang kompetensi dan kinerja akademik sama-sama dapat menjelaskan perannya secara langsung untuk meningkatkan kepuasan mahasiswa kelas international Fakultas Ekonomi dan Bisnis pada Universitas SIngaperbangsa Karawang

2. Terdapat pengaruh simultan kompetensi dosen dan kinerja akademik terhadap kepuasan mahasiswa kelas international Fakultas Ekonomi dan Bisnis pada Universitas Singaperbangsa Karawang sama-sama dapat menjelaskan perannya secara langsung 
untuk meningkatkan kepuasan mahasiswa kelas international Fakultas Ekonomi dan Bisnis pada Universitas Singaperbangsa Karawang.

\subsection{Saran}

Berdasarkan hasil analisis dan pembahasan tentang pengaruh kompetensi dosen dan kinerja akademik terhadap kepuasan mahasiswa pada kelas International Fakultas Ekonomi dan Bisnis Universitas Singaperbangsa Karawang, maka dirumuskan saran sebagai berikut.

Perlu kajian lebih lanjut tentang variabel lainnya yang mempengaruhi variabel-variabel lain selain kompetensi dosen dan inerja akademik yang berpengaruh pada kepuasan mahasiswa.

Diharapkan bagi peneliti selanjutnya agar meneliti variabel variabel lain di luar kompetensi dosen dan kinerja akademik yang berpengaruh pada kepuasan mahasiswa.

Kepada mahasiswa, tim penulis bisa menyarankan hal-hal sebagai berikut:

a. Mahasiswa hendaknya mengikuti kegiatan pembelajaran dengan selalu bersemangat dan menghargai dosen baik di saat memberikan pembelajaran maupun di luar pembelajaran. Mahasiswa juga bisa memberikan masukan atau kritikan membangun kepada dosen guna meningkatkan kompetensi yang dimiliki.

b. Mahasiswa hendaknya menggunakan fasilitas belajar yang disediakan semaksimalnya dan dengan cara yang baik. 


\section{DAFTAR PUSTAKA}

\section{Buku:}

Marwansyah. 2009. Manajemen Sumber Daya Manusia. Edisi Kedua, Alfabeta, Bandung.

Mathis, Robert L. dan John H. Jackson. 2008. Human Resource Management. $12^{\text {th }}$ edition. Thomson South-Western, USA.

Moeheriono. 2010. Pengukuran Kinerja Berbasis Kompetensi. Cetakan Kedua. Ghalia Indonesia, Bogor.

Prawirosentono, Suyadi. 2012. Manajemen Sumber Daya Manusia Kebijakan Kinerja Karyawan. Cetakan Kedua. BPFE-Yogyakarta, Yogyakarta. 
Sedarmayanti. 2011. Manajemen Sumber Daya Manusia Reformasi Birokrasi dan Manajemen Pegawai Negeri Sipil. Cetakan Kelima. Refika Aditama, Bandung.

Sudarmanto. 2009. Kinerja dan Pengembangan Kompetensi SDM. Cetakan Pertama. PT.Pustaka Pelajar, Yogyakarta.

Sugiyono. 2013. Metode Penelitian Kuantitatif Kualitatif dan $R \& D$. Cetakan Ketiga belas. Alfabeta CV. Bandung.

Sutrisno, Edy. 2013. Manajemen Sumber Daya Manusia. Cetakan Kelima. Kencana Prenada Media Group, Jakarta.

2006. Manajemen: Dasar, Pengertian, dan Masalah. Edisi Revisi. PT. Bumi Aksara, Jakarta.

Umar, Husein. 2010. Desain Penelitian MSDM dan Perilaku Karyawan : Paradigma Positivistik dan Berbasis Pemecahan Masalah. Rajawali Pers : Jakarta.

\section{Jurnal:}

Long, Choi Sang and Zaiton Ibrahim and Tan Owee Kowang. 2014. An Analyis on the Relationship between Lecturer's Competencies and Students' Satisfaction. International Education Studies. Vol. 7 No. 1. 2014. Canadian Center of Science and Education. ISSN 1913-9020. E-ISSN 1913-9039

Parasuraman, Berry and Zeithaml. An Empirical Examination of Relationships in an Extended Service Quality Model," Marketing Science Institute Research Program Series, December 1990, Report No. 90-122. 
ISSN : 2541-6995

Vol 3 No 1 November 2018

50 | Buana IImu 
ISSN : 2541-6995

Vol 3 No 1 November 2018

51 | B u a n a | I m u 